ORIGINAL ARTICLE

\title{
A cost benefit analysis of an enhanced seat belt enforcement program in South Africa
}

\section{G T Harris, I A Olukoga}

See end of article for authors' affiliations .....................

Correspondence to: Professor G T Harris, School of Economics \& Management, University of KwaZulu-Natal, Durban 4041, South Africa; harrisg1@ukzn.ac.za
Objective: To examine whether a program to increase the wearing of seat belts in a South African urban area would be worthwhile in societal terms.

Design: A cost benefit analysis of a one year enhanced seat belt enforcement program in eThekwini (Durban) Municipality.

Methods: Data were drawn from two main sources - a 1998 study of the cost of road crashes in South Africa and, given the absence of other data, a meta-analysis of the effectiveness of various types of interventions to reduce road crash casualties in the United States-and were analyzed using cost benefit analysis.

Results: A program designed to enforce greater wearing of seat belts, estimated to cost 2 million rand in one year, could be reasonably expected to increase seat belt usage rates by 16 percentage points and reduce fatalities and injuries by $9.5 \%$. This would result in saved social costs of 13.6 million rand in the following year or a net present value of 11.6 million rand. There would also be favorable consequences for municipal finances.

Conclusions: Investment in a program to increase seat belt wearing rates is highly profitable in societal terms.
C rashes involving motor vehicles are a major cause of death in developed countries, but the various strategies and interventions which have been applied in those countries have resulted in impressive declines in motor vehicle related death rates. Such rates remain high in developing countries ${ }^{1}$ and there has been much consideration of which interventions might be applied to them..$^{2-4}$ This article considers a specific intervention in a South African urban municipality.

\section{SOUTH AFRICAN ROAD CRASH DATA}

A comprehensive study ${ }^{5}{ }^{6}$ has estimated that there were 511605 road traffic crashes in South Africa in 1998, of which 80622 involved death or injury. These latter crashes resulted in 5616 deaths and 92827 injuries and cost an estimated 12697 billion rand $(\mathrm{R} 7=$ approximately US\$1). Sixty percent of this cost involved damage to vehicles and other property. This article focuses on a subset of these crashesthe 49255 which involved injury to drivers and/or passengers (pedestrians made up 38\% of total fatalities and 23\% of injuries )—which had a total cost of R4.7 billion. It further focuses on non-property damage, and specifically on the value of lost output, the costs of pain and suffering, and hospital/medical and funeral costs.

The human cost is made up of fatalities (immediate death or death in less than seven days after the crash), serious injuries (which necessitate hospitalisation or confinement to bed) and slight injuries (for example, cuts and bruises, sprains, and light shock). The value of lost output is based on the reduced income earned by crash victims over their lifetimes. The estimates take into account the age profile of the victims, the likelihood that some would have died by the age of 65 years for other reasons, and their employment status. A death was valued at R331 000 in 1998 values.

The medical and hospital cost estimates in the Department of Transport's report ${ }^{5}$ were derived from the Compendium of Health Statistics: South Africa ${ }^{7}$ which is based on annual returns made by district and regional hospitals. These estimates include the average length of time which crash victims spend in hospital-1.5 days each for victims who subsequently died or who were slightly injured, and 17.5 days for those who were seriously injured. Funeral costs were estimated as the difference between the current cost of a funeral and the discounted cost of a funeral at the "normal" time of death. The estimate of the cost due to "pain, suffering, and loss of amenities of life" was based on Road Accident Fund (a national insurance scheme to compensate the victims of road crashes) payouts to crash victims and compensation ordered by the courts. The study estimates a figure of R15 182 for serious injury and R2356 for a slight injury. These figures may be regarded as expressing society's assessment of the psychological costs of road crashes to the victims, but they do not include costs suffered by the family of the victim.

It was not possible to divide administrative, legal, and miscellaneous costs between their human and property damage components, but if a little under half is attributed to human costs, this provides a convenient R3000 million as the total human cost of road crashes involving driver and/or passenger casualties in South Africa in 1998. The break up between the four cost components is presented in table 1 . Loss of output made up $65 \%$ of total human costs and $84 \%$ of this was due to fatalities. The unit costs presented in table 1 are expressed in 1998 values, having been discounted at $8 \%$.

\section{INCREASING SEAT BELT USAGE}

An increase in the wearing of seat belts will reduce these costs because some fatalities will be "converted" into serious injuries, slight injuries, or to no injuries; some serious injuries will become slight injuries or no injuries; and some slight injuries will become no injuries. It is also possible that the wearing of seat belts could increase the severity of injury (for example, if drivers or passengers were trapped by their seat

Abbreviations: CBA, cost benefit analysis; NPV, net present value; UNIARC, University of KwaZulu-Natal's Interdisciplinary Accident Research Centre. 
Table 1 Total human costs of road crashes resulting in driver and/or passenger casualties, 1998 (millions of rands)

\begin{tabular}{lclrr}
\hline Cost component & Slight injury & Serious injury & Fatal & Total \\
\hline Loss of output & 31 & 285 & 1635 & 1951 \\
$\begin{array}{l}\text { Pain and } \\
\text { suffering }\end{array}$ & 124 & 328 & 105 & 557 \\
$\begin{array}{l}\text { Hospital/medical } \\
\text { and funeral }\end{array}$ & 25 & 231 & 91 & 347 \\
$\begin{array}{l}\text { Other } \\
\text { Total }\end{array}$ & 43 & 73 & 29 & 145 \\
\hline
\end{tabular}

$44 \%$ of the administrative, legal, and other costs associated with these crashes are assumed to be human costs.

belts in a burning or submerged vehicle) but these are rarer than cases where occupants are able to escape because they did not lose consciousness due to serious injuries. Conversely, seat belts do cause contusions. It is also possible that drivers wearing seat belts might become more reckless and inclined to take risks, ${ }^{89}$ in which case the benefits of drivers wearing seatbelts could be offset by an increase in crashes, in deaths and injuries to vehicle occupants not wearing seat belts, and to pedestrians. We have no evidence concerning this possibility for South Africa but the data we use incorporate these possible effects into estimates of the effects of increased seat belt wearing.

There are few studies of the effectiveness of seat belt usage in developing countries and none, to our knowledge, for South Africa. We have therefore used data from the United States, where a major meta-analysis ${ }^{10}$ found that wearing lap and shoulder seat belts reduced deaths by $45-60 \%{ }^{11}$ and serious injuries by $50-83 \% .{ }^{12}$ Lap belts alone, as often worn by back seat passengers, reduced deaths by $17-58 \%{ }^{13-15}$ We discuss the implications of using these US data in the Conclusion. How, then, might the proportion of drivers wearing seat belts be raised? Six main interventions are recognized: safety belt laws, primary enforcement of these laws (that is, allowing police to stop and charge drivers for not wearing seat belts, as opposed to charging them only if they are stopped for other offences), enhanced enforcement programs, incentives, and mass media and education programs. The meta-analysis examined the first three and found each to be strongly effective. ${ }^{10}$ Only two studies have adequately measured the effect of enhanced enforcement programs on road crash casualties. ${ }^{16}{ }^{17}$ These reported an initial median increase in seat belt use by 16 percentage points, which fell to nine percentage points after six months ${ }^{17}$ and 24 months, ${ }^{16}$ with a consequent long term reduction in fatalities and injuries of $11 \%$.

This article applies cost benefit analysis (CBA) to examine whether the costs to society of an enhanced enforcement program to increase seat belt usage in the eThekwini (Durban) Municipality would be justified by the social benefits resulting from their greater use.

\section{METHODS}

Cost benefit analyses involve four main steps:

- Identification of all the relevant costs and benefits.

- Placing money values on these costs and benefits where possible.

- Converting the stream of future values into comparable terms (known as discounting to present value).

- Calculating overall measures by which a project or program may be judged, usually its net present value (NPV).
Table 2 Unit costs of road traffic crashes resulting in driver and/or passenger casualties, South Africa, 1998 (rands)

\begin{tabular}{lccc}
\hline Cost component & Slight injury & Serious injury & Fatalities \\
\hline Loss of output & 466 & 10811 & 291132 \\
$\begin{array}{l}\text { Pain and suffering } \\
\text { Hospital, medical, and }\end{array}$ & 376 & 12443 & 18697 \\
funeral & 647 & 8763 & 16204 \\
$\begin{array}{l}\text { Other } \\
\text { Total }\end{array}$ & 3355 & 35142 & 5163 \\
& & 331196 \\
\hline $\begin{array}{l}\text { 44\% of the administrative, legal, and other costs associated with these } \\
\text { crashes are assumed to be human costs. }\end{array}$
\end{tabular}

CBA typically involves a capital investment in one year (for example, the construction of an irrigation scheme) and a stream of net returns that follow over a number of years (for example, the value of increased agricultural output minus costs). The benefits may take the form of saved costs, as they do in this study.

The main benefits of increased seat belt usage are the saved costs from reduced loss of life and fewer serious injuries. The value of saved lives is measured by the earnings of these individuals, which are assumed to reflect the economic value to society of their work contribution. The value of fewer serious injuries is measured by reduced medical and hospital costs plus a reduction in lost working time.

The costs of achieving a given increase in seat belt usage are the human and physical costs of the chosen program or mix of programs. Of the six interventions identified earlier, seat belt laws and their primary enforcement already operate in South Africa. Advice from the University of KwaZuluNatal's Interdisciplinary Accident Research Centre (UNIARC) suggests that encouragement to use seat belts without any increase in the likelihood of prosecution for failing to do so is likely to be of very limited effectiveness (personal communication, UNIARC, August 2003). We therefore base our analysis on an enhanced enforcement program. Such a program might be organised in a number of ways. We assume the employment of an additional 10 police to focus exclusively on seat belts which would have a budgetary cost of around R200 000 each per annum (personnel communication, Durban Metro Police, November 2003).

In summary, the resource costs are the additional expenditures incurred in an effort to increase seat belt usage and the resource benefits are the savings in lost output as a result of fewer deaths and fewer/less severe injuries, reduced costs of pain and suffering, and reduced hospital/medical and funeral expenses. Following CBA best practice, a net present value is estimated which can be interpreted as the profit or loss to society as a result of investment in the program.

\section{ASSUMPTIONS AND PROCEDURES}

The CBA was set up using the following assumptions:

(a) The investment comprises the financial costs of mounting a program for one year aimed at increasing the extent of seat belt wearing. The program involves the employment of 10 additional Metro Police who would focus exclusively on issuing fines to non-wearers of seat belts. The program cost is estimated at R2.0 million.

(b) The benefits comprise the value of output from saved lives and reduced injuries, reduced cost of pain and suffering, and reduced hospital, medical, and funeral costs resulting from the campaign. Saved costs can be estimated by dividing the relevant total cost figures in table 1 by the numbers of drivers and passengers injured or killed. The results are reported in table 2, which shows that a fatality costs R331 000, of which $88 \%$ results from lost output. 
Table 3 Fatalities and injuries and their human cost, eThekwini Municipality, 1998

\begin{tabular}{lccc}
\hline Categories & $\begin{array}{l}\text { Number of } \\
\text { victims }\end{array}$ & $\begin{array}{l}\text { Cost per } \\
\text { victim (rands) }\end{array}$ & $\begin{array}{l}\text { Human cost } \\
\text { (millions of rands) }\end{array}$ \\
\hline Slight injury & 6119 & 3355 & 20.5 \\
Serious injury & 1211 & 35142 & 42.6 \\
Fatality & 237 & 331196 & 78.5 \\
Total & 7567 & & 141.6 \\
\hline
\end{tabular}

(c) Benefits will vary according to the effectiveness of the program in increasing seat belt wearing. It is assumed that usage initially increases from the present (2001) figure of $32 \%$ in urban areas of KwaZulu-Natal ${ }^{18}$ by 16 percentage points to $48 \%$ by the end of the year of enforcement.

(d) We conservatively assume that seat belts are 50\% effective and that wearing a seat belt reduces the likelihood of fatalities and injuries by $9.5 \%$ - that is, $0.16 \times 0.50 /(1-$ $0.32 \times 0.50)$. We noted earlier that lap and shoulder seat belts are more effective than lap belts. Since 1995, all new cars in South Africa, whether imported or domestically produced, must have lap and shoulder belts in the front seats and lap belts in the rear and many have lap and shoulder belts throughout (personal communication, UNIARC, February 2004).

(e) The number of crashes is assumed to remain constant.

\section{RESULTS}

Fatalities and injuries from road crashes in the Municipality during 1998 are presented in column 1 of table $3 .{ }^{19}$ To these are applied the cost figures from table 2, resulting in an estimated total cost of injuries and deaths from road crashes of R141.6 million.

The long term effects of the program in terms of reduced fatalities and injuries are presented in table 4, assuming a 16 percentage point increase in seat belt usage and a $9.5 \%$ fall in injuries and fatalities. In absolute terms, fatalities fall by 23 per annum and injuries (combined) by 696. The human cost from the same number of crashes falls by R13.6 million to R128.0 million and the NPV of the program is R11.6 million. Because some people who start wearing seat belts due to the enforcement program will continue wearing them when the program ends, the program will yield additional benefits in future years. Our analysis excludes these benefits.

In addition to the positive social benefits, there is also likely to be a favourable impact on municipal finances. The cost of employing an additional 10 police would be R2 million. If they each fined 10 offenders per day at R250 (the current fine) per offence, and $50 \%$ of these fines were paid (the current rate), this would add R3.25 million per annum to municipal finances-a net gain of R1.25 million per annum.

\section{CONCLUSION}

Cost benefit analysis has shown that an investment of R2 million in an enhanced seat belt enforcement program can be reasonably expected to yield a net present value to society in that year of R11.6 million. In addition to these positive net benefits to society, municipal finances will be favorably affected.

A limitation of the analysis is its use of US data on seat belt effectiveness and the effect of enforcement program, given the lack of evidence from South Africa or other developing countries. To judge the potential seriousness of this, we carried out a breakeven analysis to show how much seat belt usage would have to increase in order to yield social benefits equal to the costs of the enforcement programme, assuming
Table 4 Fatalities and injuries and their human cost assuming a 16 percentage point increase in seat belt usage over one year

\begin{tabular}{llcc}
\hline Categories & $\begin{array}{l}\text { Number of } \\
\text { victims }\end{array}$ & $\begin{array}{l}\text { Cost per victim } \\
\text { (rands) }\end{array}$ & $\begin{array}{l}\text { Human cost (millions of } \\
\text { rands) }\end{array}$ \\
\hline Injuries & 6634 & 8607 & 57. \\
Fatalities & 214 & 331196 & 70.9 \\
Total & 6735 & & 128.0 \\
\hline
\end{tabular}

Injury cost per victim is the weighted mean of the two classes of injury in table 3. The first column derives from column 1 of table 3 , with a $9.5 \%$ reduction in deaths and injuries.

the same ratio between increased usage and reductions in deaths and injuries. A 2.5 percentage point increase in usage would result in a $1.5 \%$ reduction in deaths and injuries $(0.025 \times 0.50 /(1-0.32 \times 0.50)$, a social benefit of R2.125 million and an NPV of R125000. In the opinion of UNIARC (personal communication, October 2004), a 2.5 percentage point increase is well below the increase in seat belt usage they would expect.

The analysis could be expanded in several ways. We could consider an extension of the one year program. Subsequent years' programs would presumably achieve smaller increments in seat belt usage, and therefore lower social benefits, as time went on. We could consider whether a scaled down program might be appropriate, because some drivers and passengers would have developed the habit of seat belt wearing and would not therefore need the threat of prosecution. This would, incidentally, reduce the returns to subsequent enforcement programs. Such extensions, although interesting, would be subject to considerable debate and might cloud the very clear message of this article-that a program to increase seat belt usage is likely to yield very high returns to society.

\section{Key points}

- The costs of a one year enhanced seatbelt enforcement program in eThekwini would be modest at around US\$300 000 .

- Such a programme would be highly beneficial in terms of saved lives and injuries and is estimated to result in a net present value of $\$ 1.7$ million.

- The programme would recover its financial costs to the Municipality through revenue from fines.

- Even if the programme ended after one year there would be ongoing benefits because, even though seatbelt wearing rates would fall, they would stabilize at a rate greater than before the programme.

\section{Authors' affiliations}

G T Harris, I A Olukoga, School of Economics \& Management,

University of KwaZulu-Natal, Durban, South Africa

\section{REFERENCES}

1 Odero W, Garner P, Zwi A. Road traffic injuries in developing countries: a comprehensive review of epidemiological studies. Trop Med Int Health 1997; 2:445-60.

2 Forjuoh S, Li G. A review of successful transport and home injury preventions to guide developing countries. Soc Sci Med 1996;43:1551-60.

3 Ghaffer A, Hyder A, et al. Interventions for control of road traffic injuries: review of effectiveness literature. J Pak Med Assoc 2002;52:69-73. 
4 Foriuoh S. Traffic-related injury prevention interventions for low-income countries. Inj Control Saf Prom 2003;10:109-18.

5 Republic of South Africa, Department of Transport. An estimate of the unit cost of road traffic collisions in South Africa for 1998. Pretoria: Department of Transport).

6 Republic of South Africa, Department of Transport. Methodology for the determination of the unit cost of road traffic collisions in South Africa as an input into economic evaluation. Pretoria: Department of Transport, 1999.

7 Department of Health. Compendium of Health Statistics: South Africa. Pretoria: Department of Health, 1999

8 Adams J. Seat belt legislation: the evidence revisited. Safety Sci 1994; 18:135-52.

9 Richens J, Imrie J, Copas A. Condoms and seat belts: the parallels and the lessons. Lancet 2000;355:399-403.

10 Dinh-Zarr T, Sleet $D$, et al. Reviews of evidence regarding interventions to increase the use of safety belts. Am J Prev Med 2001;21:48-65.

11 Evans L. The effectiveness of safety belts in preventing fatalities. Accid Anal Prev 1986;18:229-41.

12 National Highway Traffic Safety Administration. Fourth report to Congress: effectiveness of occupant protection systems and their use. Washington, DC:
US, Department of Transportation, National Highway Traffic Safety Administration, 1999. DOT HS 808919.

13 Kahane C. Fatality and injury reducing effectiveness of lap belts for back seat occupants. Warrendale, PA: Society of Automotive Engineers, Paper No 870486, 1987.

14 Evans L. Traffic safety and the driver. New York: Van Nostrand Reinhold, 1991.

15 Padmanaban J, Ray R. Safety performance of rear seat occupant restraint systems. 36th STAPP Car Crash Conference Proceedings. Warrendale, PA: Society of Automotive Engineers, 1992, SAE publication no P-261.

16 Jonah B, Grant B. Long-term effectiveness of selective traffic enforcement programs for increasing seat belt use. J Appl Psychol 1985;70:257-63.

17 Williams A, Reinfurt D, Wells J. Increasing seat belt use in North Carolina. J Safety Res 1996;27:33-41.

18 Republic of South Africa. Department of Transport. Seat belt Rates-Summary of results of Traffic Offence Monitoring Survey. Pretoria: Department of Transport, 2003.

19 Durban City Engineers Unit. Road Traffic Accident Statistics-Durban Metropolitan Area 1998-1999, Durban, Durban Metropolitan Transport Advisory Board, 2001. 